\title{
Digital socialization of students by means of educational media
}

\author{
Marina Podbolotova ${ }^{1 *}$, Valentina Dmitrieva ${ }^{2}$, Ruslana Reznikova ${ }^{3}$, Yulia Grishaeva ${ }^{4}$, and \\ Zinaida Tkacheva ${ }^{5}$ \\ ${ }^{1}$ Moscow City University, Directorate of Educational Programs, Moscow, Russia \\ ${ }^{2}$ Moscow City University, Department of Geography and Tourism, Moscow, Russia \\ ${ }^{3}$ Association of Teachers Working with Gifted Children, Moscow, Russia \\ ${ }^{4}$ Moscow Region State University, Department of Pedagogy, Mytishchi, Russia \\ ${ }^{5}$ Moscow Region State University, Department of Physical Geography, Environmental Management \\ and Methods of Teaching Geography, Mytishchi, Russia
}

\begin{abstract}
The article is devoted to the problem of determining the factors of the effectiveness of digitalization of education, which is motivated by the unprecedented rapid transition of educational organizations to e-learning using distance educational technologies not only in Russia but also in most countries of the world. One of these factors is the level of digital socialization of all the participants of the educational process. Digital socialization is considered to be a feature of a new form of socialization of a modern person. The novelty of the research is in the determination of a set of key characteristics of educational media content that forms and develops digital competence, as well as increases the level of digital socialization of all the participants of the educational process. The study identifies the main ideas of an educational media project that has the following characteristics: it is "cognitive" and "congruent" (aimed at forming the information and media competence); it is "conative", "constructive", "conformal", and "comic" (aimed at forming the communication competence); it is "creative" and "constructive" (aimed at forming the technical competence); finally, it is "conformal" (aimed at forming the consumer competence). Distance educational projects, which in practice acquire the identified characteristics, expand the functionality of educational media and their ability to influence children's educational results.
\end{abstract}

Keywords: digitalization of education, digital socialization, educational content, educational media.

\section{Introduction}

The specifics of educational process organization in the spring of 2020 identified the weaknesses and the further development areas of pedagogical technologies, as well as means of education. Besides, it became possible in a short time to assess the readiness of educational systems to change due to environmental conditions. Even gradual improvements in the field of online learning "seriously transform organizational principles and forms of education and

\footnotetext{
*Corresponding author: podbolotovami@mgpu.ru
} 
enhance the mediation of subject-subject interactions by digital technologies" [1]. However, we faced the rapid transition to e-learning, using distance learning technologies. Such a transition leads either to the transformation and re-emergence of the entire system or its certain elements or to its degradation and destruction. The short duration of the forced experiment carried out on a global scale in 2020, saved the education system from collapse. Although it did not allow seeing either negative or positive results, it provided an opportunity to assess the factors of success and failure [2-4]. One of these factors was the level of digital socialization of all the participants of the educational process.

What is digital socialization and how to determine its presence or absence? Digital socialization is considered to be a feature of a new form of socialization of a modern person, which reflects both the process of social adaptation and integration of a person in the context of digitalization of the life of society and the process of gaining new social experience based on online contexts by a person, as well as the use of information and communication technologies that form the so-called "digital identity". The digital identity, in turn, is the result of the digitization of personal data, individual needs, activities, relationships, biography, and habits [5]. The process of integration of the digital and real persons is inevitable. The main sources of development and factors of digital socialization are the Internet, which is a "habitat" and a "significant mediator between the child and the environment", as well as digital devices, which are "cultural tools that contribute to the emergence of new forms of activity, cultural practices, phenomena, and meanings" [5]. In other words, "Internet socialization", "cyber socialization", and "digital socialization" become synonyms. In turn, the level of digital socialization is considered to be a measure of a person's acceptance of new technologies, attitude towards them, as well as the quality of response to global technological challenges of modern times [6-7]. Yet, what are the characteristics of educational content, product, or project that can increase the level of digital socialization and competence? The rapid transition of education to e-learning provides us with a huge layer of cases for research and reflection. The volume of digital educational content has increased significantly, but we will consider only several products, that, in our opinion, were successfully digitized.

Case 1. Project "Sciencely. Smart Moscow". To sum everything up, it is a science populariser for children and adults. The participants conduct experiments and get acquainted with science (chemistry, biology, medicine, geography, geology) in an adult way: "there are scientists instead of animators, thoughtful experiments instead of dry ice, and all this is a part of the game" (https://sciencely.ru). At the same time, while the children are experimenting, parents are learning new things about science in the format of humorous shows (Stand Up Science, Science Slam) or quizzes. The project is effectively developing; it is presented in 37 cities and eight countries. In 2019, 120,000 families took part in the project. The products presented in the project represent a merger of educational, marketing, and media formats: the presentation of educational material through a story, where the participant becomes the hero; the presence of "adult" tasks and, at the same time, simple and safe performance; the presence of an interactive platform, which can be a storyteller, an interlocutor, and a guide; a combination of online format and elements of a real laboratory; simultaneity of gaming and the possibility of living social roles; sufficiency of resources for independent repetition of experiments; "craft" packaging.

Case 2. Shop "I love reading" (https://detiknigi.ru). A small bookstore that sells mainly the products of its publishing house. The main product that deserves attention in the context of our research is the "Fairy Tale School" project. It is an educational online project that helps children to form the basic skills of creating texts: to start with the opening and develop a story, using climax and resolution; to learn how to write poetry: to see the structure, rhythm, and rhyme and, therefore, to understand and love poetry (Children Publishing House "Nastya and Nikita", 2020). Children see the results immediately: they receive a part of a tale or a 
poem written with the help of a mentor, and at the end of the course, they get their literary products, a publication on the website, and an electronic diploma.

\section{Methods}

During the study, more than 50 educational and popular science online projects were analyzed in addition to the above-mentioned cases, including the Russian Electronic School (resh.edu.ru), the Moscow Electronic School (uchebnik.mos.ru), MOSOBR.TV (mosobr.tv), Uchi.ru (uchi.ru), Foxford (foxford.ru), video lessons library (interneturok.ru), publishing house of Yandex (yandex.ru/izdatelstvo), Yandex.School (school.yandex.ru), Yandex.Education (education.yandex.ru), Yandex.Practicum (praktikum.yandex.ru), 1C: Education 5. School (obrazovanie.1c.ru), New disk. Education (www.nd.ru), courses (kursitet.ru), lectures (lektorium.tv), Matklass (matclass.ru), Museum of Living History (zhivayaistoriya.ru), GetAClass, IQclub (hiqclub.ru), Chess (chess.com), etc. Besides, a private educational initiative was analyzed, including unique educational programs and marathons on social networks and messengers (Instagram, Telegram) by such authors as Nika Aksutina, Tatiana Pirozhenko, etc. [8].

\section{Results}

During the conducted content analysis, the general features of modern educational projects that have the potential for active digital socialization of students were identified:

- the basis of an educational product that implies distance learning can be both a specially organized digital interactive online platform and printed teaching materials or simple tasks in the format of a quest, challenge, or marathon on social networks;

- educational content presupposes not only a vivid visual component but also an obligatory activity component, from formal tests to creating a personal product or even a real project;

- a distance educational resource, as a rule, stimulates communication on the Internet, surprises with its novelty, and has a viral potential (people want to talk about it and take an active part) [9];

- the minimal functionality of a distance educational resource, as a rule, does not imply any financial investments from the user and does not require the mandatory purchase of any options to ensure the availability of education.

\section{Discussion}

Thus, distance educational projects that acquire the above-mentioned features become independent media projects initiated by different actors (such as educational organizations, companies that work in the field of education and culture, manufacturing and trade enterprises) [10].

Such media projects become a communication platform, regardless of how actively their participants use digital resources. A child's perceived need to use modern digital tools is more important than the volume [11]. In this case, the role of communication technologies is growing, and the functionality of educational media is expanding: the formation of a specially organized, emotionally colored, personally significant educational environment for the user. It should be assumed that there is a relationship between educational motivation and the level of digital socialization, but this is a topic for another research [12].

During the process of designing educational media that involve active digital socialization, one can use the conventional $7 \mathrm{C}$ principle. It was borrowed from the field of marketing communications management for consumer brands [13]. It is advisable to describe 
the general idea of a media project and its elements using a list of the following characteristics: it should be 1) creative; 2) conative; 3) cognitive; 4) constructive; 5) conformal; 6) comic; 7) congruent.

\section{Conclusion}

The study made it possible to conclude that the main characteristics (or the functional combinations) of an educational media project and educational results correspond. To be more precise, cognitive and congruent criteria are aimed at forming the information and media competence of students; conative, constructive, and comic are aimed at forming the communication competence; creative and constructive are aimed at forming the technical competence; conformal is aimed at forming the consumer competence of schoolchildren. The presented types of competencies, in their entirety, determine the level of digital competence, that is, "the readiness and ability of a person to apply info-communication technologies confidently, effectively, critically, and safely in different spheres of life (information environment, communications, consumption, and technosphere) [5]. In turn, digital competence, along with cultural practices, online risks, online space characteristics, the concept of a digital personality, and the quality of digital world relations, determines the main areas of change and development vectors of digital socialization.

\section{Acknowledgments}

The reported study was funded by the Russian Foundation for Basic Research according to the research project No. 19-013-00322 "Multicultural design of ecological development of personality in digital education".

\section{References}

1. L. Mishra, T. Gupta, A. Shree, International Journal of Educational Research Open, 1, 100012 (2020) https://doi.org/10.1016/j.ijedro.2020.100012

2. Suyadi, Z. Nuryana, N.A. Febriana Fauzi, International Journal of Disaster Risk Reduction, 51, 101848 (2020). https://doi.org/10.1016/j.ijdrr.2020.101848

3. A. Li, M. Harries, L.F. Ross, The Journal of Pediatrics, 227, 34-44 (2020) https://doi.org/10.1016/j.jpeds.2020.08.069

4. G.U. Soldatova, Social Psychology and Society, 9(3), 71-80 (2018) https://doi.org/10.17759/sps.2018090308

5. J.S. Peifer, T. Yangchen, SAGE Open, 7(2) (2017) https://doi.org/10.1177/2158244017710493

6. O. Pei-Boonhttps, W.M. Wan Jaafar, A. Chin-Siang, and C. Nee-Nee, SAGE Open, 10(1) (2020). https://doi.org/10.1177/2158244020902076

7. M.I. Podbolotova, R.A. Reznikova, Cognitive and Activity Practices of The City: Cases of Moscow, in Education and City: partnership for success, Moscow City University, 16-18 May 2019, Moscow, Russia (2020)

8. T.Z. Aldahdouh, P. Nokelainen, V. Korhonen, SAGE Open, 10(1) (2020). https://doi.org/10.1177/2158244019899441

9. A.-M. Iversen, A.S. Pedersen, L. Krogh, A.A. Jensen, SAGE Open, 5(4) (2015). https://doi.org/10.1177/2158244015608423 
10. R.A. Reznikova, K.S. Reznikov, Generation Z: Challenge to The System of Education in The Context of Society and Youth Culture Transformation, in Education and City: partnership for success, Moscow City University, 16-18 May 2019, Moscow, Russia (2020)

11. X. Yang, D. Li, X. Liu, J. Tan, The Journal of Prosthetic Dentistry (to be published). https://doi.org/10.1016/j.prosdent.2020.08.004

12. T.Y. Krotenko, Innovatsionnaya ekonomika: perspektivy razvitiya i sovershenstvovaniya [Innovative economy: prospects for development and improvement], 2(44), 46-50 (2020)

13. H. Jenkins, M. Ito, D. Boyd, Participatory culture in a networked era: A conversation on youth, learning, commerce, and politics (Polity Press, Cambridge, 2016) 